\title{
Peran Tokoh Adat Dalam Melestarikan Pernikahan Adat Mata Malam Subsuku Dayak Sawe
}

\author{
Juri', Septha Suseka² \\ ${ }^{1}$ Pendidikan Pancasila dan Kewarganegaraan, STKIP Persada Khatulistiwa Sintang, Email: jurisaputra85@gmail.com; \\ ${ }^{2}$ Pendidikan Pancasila dan Kewarganegaraan, STKIP Persada Khatulistiwa Sintang, Email: cekgupapakebenaran@gmail.com
}

INFO ARTIKEL
Riwayat Artikel:
Diterima: 06 September
2020
Disetujui: 30 September
2020

Kata Kunci:

Tokoh adat

Pernikahan adat mata malam

Sub suku Dayak Sawe

\begin{abstract}
ABSTRAK
Abstrak. Penelitian ini bertolak dari fenomena bahwa mulai lunturnya pelaksanaan pernikahan adat mata malam subsuku Dayak Sawe. Tujuan penelitian adalah untuk mendeskripsikan peran tokoh adat dalam melestarikan pernikahan adat mata malam pada subsuku Dayak Sawe. Penelitian ini menggunakan pendekatan kualitatif deskriptif dengan jenis studi etnografi. Teknik pengumpulan data dilakukan dengan observasi, wawancara dan dokumentasi. Teknik analisis data dilakukan dengan reduksi data, penyajian data dan penarikan kesimpulan. Hasil penelitian menunjukkan bahwa (1) makna yang terkandung dalam pernikahan adat mata malam, yaitu kerukunan, ketaatan, keseimbangan hubungan manusia dengan Tuhan, alam dan sesama. (2) kendala yang dihadapi tokoh adat, yaitu teknologi komunikasi, masuknya budaya luar, generasi muda lebih tertarik pada budaya modern, masuknya agama Kristen yang menekankan tentang iman daripada tradisi (3) upaya yang dilakukan, antara lain tokoh adat melibatkan anak usia muda dalam setiap kegiatan adat, memberikan pemahaman kepada masyarakat bahwa menikah secara adat sangat penting sebagai upaya menjaga kelestarian adat dan cinta akan adat.
\end{abstract}

\begin{abstract}
This research departs from the phenomenon that the start of the fading of the traditional marriage mata malam of the subsuku Dayak Sawe. The purpose of this study was to describe the role of traditional leaders in preserving the traditional marriage mata malam of the subsuku Dayak Sawe. This research uses a descriptive qualitative approach to the type of ethnographic study. Data collection techniques are done by observation, interview and documentation. Data analysis technique is done by data reduction, data presentation and conclusion drawing. The results showed that (1) the meaning contained in the traditional wedding of the night eye, namely harmony, obedience, the balance of human relations with God, nature and others, (2) the obstacles faced by traditional leaders, namely communication technology, the entry of foreign cultures, the younger generation being more interested in modern culture, the inclusion of Christianity which emphasizes faith rather than tradition (3) efforts are made, including traditional leaders involving young children in every customary activity, provides an understanding to the community that marrying in a customary manner is very important as an effort to preserve custom and love for adat.
\end{abstract}

\section{A. LATAR BELAKANG}

Setiap daerah memiliki kebudayaannya sendiri dan kebudayaan tersebut sejatinya tetap dipertahankan dan dipelihara walaupun generasi terus berganti. Kebudayaan sebagai sebuah identitas dari suatu etnik seringkali cepat pudar karena ditinggalkan pewarisnya. Oleh karena itu, ada orang-orang tertentu yang bersusah payah berusaha mempertahankan dengan harapan budaya tersebut tidak hilang. Kebudayaan dapat diartikan sebagai sesuatu yang sengaja diciptakan oleh manusia dengan bentuk kegiatan yang sering dilakukan serta dianggap baik. kebudayaan adalah keseluruhan gagasan dan karya manusia yang harus dibiasakan dengan belajar, beserta keseluruhan dari hasil budi dan karyanya itu[1].

Kebudayaan berkenaan dengan keseluruhan cara hidup anggota masyarakat meliputi bagaimana mereka berpakaian, adat kebiasaan perkawinan dan kehidupan keluarga, pola-pola kerja mereka, upacara-upacara keagamaan dan pencarian kesenangan. Kebudayaan meliputi juga barang-barang yang mereka ciptakan dan yang bermakna bagi mereka seperti busur dan anak panah, bajak, pabrik dan mesin, komputer, buku, tempat kediaman. Kesimpulannya bahwa kebudayaan adalah keseluruhan gagasan dan karya manusia yang tumbuh dalam kelompok masyarakat dan terrealisir dalam bentuk kegiatan budaya seperti model berpakaian, adat kebiasaan, perkawinan adat, pola kerja masyarakat[2].

Setiap kebudayaan memiliki wujud budaya tercermin pada nilai budaya dan kebudayaan fisik, antara lain; (1) nilai budaya, seperti buah pikiran, tingkah laku, dan benda-benda tertentu; (2) kebudayaan fisik,seperti tarian, nyanyian, ukiran, patung, anyaman, mantra, bahasa, pantun, bentuk pernikahan, cerita rakyat, sastra lisan, dan adat istiadat lainnya. 
Kebudayaan juga memiliki fungsi tertentu antara lain (1) sebagai pedoman hubungan manusia, dalam arti suatu kelompok budaya yang berjalan dalam suatu tujuan tertentu; (2) sebagai pemenuhan kebutuhan masyarakat artinya budaya bukan hanya persoalan adat istiadat saja, tetapi juga tentang pola pikir dan perilaku, termasuk bagaimana masyarakat dapat bertahan hidup dengan memenuhi kebutuhan hidupnya, contoh bagaimana berkebun untuk masyarakat pegunungan dan para pencari ikan di daerah pesisir pantai [3].

Kebudayaan dalam masyarakat Indonesia memiliki tiga macam yang masing-masing mempunyai corak tersendiri, sebagai berikut: (1) Kebudayaan suku bangsa (yang lebih dikenal secara umum di Indonesia dengan nama kebudayaan daerah).Kebudayaan suku bangsa artinya adalah golongan manusia yang terikat oleh kesadaran dan identitas akan kesatuan kebudayaan. Orang-orang yang tergolong dalam satu suku bangsa tertentu, mempunyai kesadaran dan identitas diri terhadap kebudayaan suku bangsanya, misalnya menggunakan bahasa daerah, mengembangkan kesenian dan adat istiadat.(2) Kebudayaan umum lokal artinya kebudayaan yang dimiliki masyarakat dalam suatu daerah meskipun penduduknya beragam etnis.(3) Kebudayaan nasional Indonesia yaitu suatu kebudayaan yang dipahami serta dapat dijadikan suatu ciri khas dari suatu bangsa. Kebudayaan nasional memiliki syarat mutlak yakni harus memiliki sifat yang khas dan dapat dibanggakan serta dapat memberikan suatu identitas bagi suatu negara. Kebudayaan nasional adalah suatu kebudayaan lokal yang diangkat dan dianggap dapat mewakili keseluruhan bangsa[4].

Bangsa Indonesia memiliki aneka ragam kebudayaan karena mempunyai banyak kelompok suku dan budaya. Setiap suku atau kelompok budaya mempunyai budaya masing-masing yang berbeda dengan kelompok budaya atau suku di daerah lain. Budaya yang muncul dan berkembang di dalam setiap kelompok budaya di Indonesia disebut dengan budaya lokal artinya suatu budaya yang berkembang karena diwariskan secara turun temurun melalui sebuah kelompok yang mendiami daerah atau wilayah tertentu. Budaya lokal adalah kebudayaan suatu suku bangsa dengan memiliki etnik tertentu dalam daerah tertentu. Jadibudaya lokal terkait dengan setiap suku bangsa yaitu golongan manusia yang terikat oleh kesadaran dan identitas akan kesatuan kebudayaan dan unsur bahasa sebagai ciri khasnya[5].

Budaya lokal adalah suatu kebudayaan yang tumbuh dan berkembang serta dimiliki dan diakui oleh masyarakat suku bangsa setempat[6]. Budaya lokal adalah kebijaksanaan manusia yang bersandar pada filosofi nilai-nilai, etika, cara-cara dan perilaku yang melembaga secara tradisional. Bentuk-bentuk budaya lokal antara lain nilai, norma, etika, kepercayaan, adatistiadat, hukum adat, dan aturan khusus dari masa lalu sampai sekarang berkembang dan menjadi kekayaan budaya lokal di Indonesia[7].

Kesimpulanya bahwa budaya lokal adalah budaya yang bertumbuh dan berkembang dalam suatu kelompok masyarakat tertentu atau dalam suatu suku bangsa, atau golongan manusia yang terikat oleh kesadaran dan identitas akan kesatuan kebudayaan yang mereka miliki bersama dan mempunyai nilai, norma, etika, kepercayaan, adat istiadat, hukum adat. Pada masyarakat desa, budaya lokal masih berkembang dengan baikkarena sebagian besar masyarakat masih mempertahankan kebudayaan yang diwariskan dari leluhurnya, seperti Gawai Dayak yang dilaksanakan setiap tahun. Namun ada juga masyarakat desa yang mengalami perubahan budaya lokal atau adanya gejala lunturnya budaya lokal, seperti yang terjadi pada masyarakat Dayak sawe.

Perubahan budaya lokal adalah gejala lunturnya budaya lokal umumnya karena masuknya budaya luar yang membawa nilai-nilai baru dan mempengaruhi pola pikir dan gaya hidup masyarakat yang sebelumnya memiliki ketaatan terhadap aturan budaya setempat namun lama kelamaan mulai ditinggalkan dan mengikuti budaya luaryang lebih modern[8]. Daerah yang umumnya menjadi sentral dari bercampurnya berbagai kelompok masyarakat, baik lokal maupun pendatang menjadi lokasi yang sulit dipertahankan budaya lokalnya dan budaya luar akan cepat mempengaruhi perubahan budaya lokal. Sedangkan wilayah desa yang tidak ada pendatang dari luar desa atau daerah sangat memungkinkan untuk mempertahankan budaya local[9].

Fenomena mulai lunturnya budaya tradisional atau lokal disebabkan karena adanya perkembangan teknologi komunikasi, adanya keinginan untuk berubah, kurangnya sosialisasi tentang budaya lokal terhadap generasi muda, masuknya budaya lain dari luar yang membawa nilai-nilai baru yang kontras dengan budaya lokal tersebut. Kehadiran teknologi komunikasi yang paling kuat mengancam keberlangsungan budaya lokal yang sudah ada sekian lama. Perkembangan teknologi komunikasi secara tidak langsung mendorong masyarakat meninggalkan unsur tradisional, walaupun sebenarnya perkembangan teknologi komunikasi mempunyai sisi positif yaitu dapat mempermudah masyarakat untuk berinteraksi, berkomunikasi, mendapat informasi dan sebagainya[10]

Di sisi lain teknologi komunikasi mempunyai sisi negatif yaitu merusak budaya lokal. Berbagai perangkat teknologi komunikasi pada kenyataannya membawa nilai atau budaya baru yang berlawanan dengan kultur dan dengan cepat dapat mengubah pola kehidupan serta gaya hidup masyarakat. Teknologi komunikasi seperti televisi, handphone, dan internet, membawa nilai-nilai yang berbeda dengan budaya lokal yang sudah ada sebelumnya. Implikasinya masyarakat dapat terpengaruh atau meniru budaya global yang dibawa 
oleh perkembangan teknologi komunikasi. Solusi yang terbaik adalah penguatan kembali pengetahuan tentang budaya lokal pada anak usia muda sebagai bentuk upaya pelestarian kebudayaan tersebut. Sosialisasi yang dilakukan memungkinkan anak muda mempunyai bekal pengetahuan sehingga dengan derasnya nilai-nilai global yang dibawa oleh perkembangan teknologi komunikasi, generasi muda sudah bisa memfilter budaya luar yang masuk sehingga tidak dapat merusak identitas suku bangsa[11].

Perubahan budaya lokal yang terjadi dalam kehidupan masyarakat ditunjukkan oleh penelitian yang sebelumnya. Nilai-nilai Kearifan Lokal dalam Perilaku Sosial Anak-Anak Remaja di Desa Sepit Kecamatan Keruak Lombok Timur. Penelitian tersebut menunjukkan adanya pergeseran nilai yang diakibatkan adanya pengaruh teknologi komunikasi lebih kuat daripada sosialisasi atau penanaman nilai-nilai yang berkembang di lingkungan keluarga, masyarakat, maupun sekolah. Nilai-nilai yang sangat dirasakan terjadi perubahan antara lain nilai kebersamaan mulai luntur karena individu sudah sibuk dengan diri sendiri, nilai komunikasi verbal secara langsung mulai kurang karena individu berkomunikasi dengan gadget[12].

Modernization and Cultural Transformation: The Expansion of Traditional Batak Toba House in Huta Siallagan, yang menunjukkan bahwa orang-orang Toba Batak sekarang sedang menghadapi dilema mempertahankan tradisi karena pengaruh modernitas. Unsur modernitas sebagai budaya baru tentunya tidak bisa dilepaskan dari perkembangan teknologi komunikasi[13]. Perubahan budaya lokal menjadi fenomena dalam kehidupan masyarakat Dayak Sawe yang sudah tidak dapat dihindari. Banyak faktor yang menjadi penyebab terjadinya pergeseran budaya, di antaranya adalah masuknya budaya baru. Budaya baru bukan hanya dibawa teknologi komunikasi, melainkan juga dihasilkan dari perubahan keyakinan yang kontras dengan budaya sebelumnya. Salah satu perubahan budaya lokal di kalangan masyarakat Dayak Sawe, adalah pada tradisi perkawinan adat.

Secara umum perkawinan merupakan hal yang kodrati baik dari aspek kebutuhan biologis maupun sosial. Dilihat dari kebutuhan biologis, perkawinan mengarah kepada upaya untuk meneruskan keturunan; sedangkan dari struktur sosial mengarah kepada kelembagaan tradisi atau adat yang ada di masyarakat. Perkawinan menurut Undang Undang Nomor 1 tahun 1974 adalah ikatan lahir batin antara seorang pria dan seorang wanita sebagai suami istri dengan tujuan membentuk keluarga atau rumah tangga yang bahagia dan kekal berdasarkan Tuhan Yang Maha Esa. [14]. Perkawinan adalah ikatan hidup bersama antara seorang pria dan wanita dengan tujuan memperoleh keturunan agar kehidupan persekutuan atau klennya tidak punah yang didahului rangkaian upacara adat. Dengan demikian pernikahan adat adalah salah satu peristiwa penting dalam kehidupan masyarakat adat, sebab perkawinan bukan hanya menyangkut kedua mempelai tetapi juga orang tua kedua kedua belah pihak, saudarasaudaranya bahkan keluarga besar mereka masingmasing.[15]. Kesimpulannya bahwa perkawinan adalah suatu ikatan antara seorang pria dan seorang wanita untuk hidup sebagai suami istri dengan setia dan suka rela serta penuh tanggungjawab tanpa ada paksaan atau tekanan dengan tujuan untuk memperoleh keturunan dan kebahagiaan.

Subsuku Dayak Sawe adalah salah satu suku Dayak Saweyang terletak di Desa Nanga Biaban Kecamatan Sekadau Hulu Kabupaten Sekadau Kalimantan Barat. Subsuku Dayak Sawe memiliki tradisi pernikahan adat yang disebut dengan pernikahan adat mata malam. Menurut AM sebagai seorang tokoh adat mengatakan pernikahan adat mata malam adalah sebuah pernikahan adat bagi kedua mempelai di hadapan tokoh adat yang disaksikan keluarga kedua mempelai. Pernikahan adat mata malam adalah sah secara adat dan kedua mempelai pun sudah bisa menjadi suami isteri meskipun mereka belum melaksanakan pesta perkawinan dan belum menikah menurut aturan agama

Beberapa tahapan pernikahan adat mata malam yang diketahui berdasarkan hasil wawancara dengan AA sebagai tokoh adat menunjukkan bahwa perkawinan Adat Dayak Sawe melalui tiga tahap yaitu tahap pertama yaitu pendekatan awal dimana pihak laki-laki mendatangi pihak perempuan mengutarakan maksud mengadakan ikatan antara anak pihak laki-laki dengan anak pihak perempuan. Pihak laki-laki mengatakan "Aku benar-benar mau ke anak omba" Pihak perempuan menjawab "auk kami nehima lamaran ahi anak omba". Selain mengutarakan maksud kedatangan tersebut pihak laki-laki juga menyerahkan barang sebagai tanda awal keterikatan.

Tahap kedua yaitu pertunangan, (dimana pihak laki-laki menyerahkan sejumlah barang kepada pihak perempuan yang semuanya dicatat dalam Surat Perjanjian Pertunangan. Isi surat perjanjian pertunangan "barangsiapa yang membatalkan pertunangan ini akan diberi sanksi adat" (Sope yang ningal ke pangan di bohie sanksi adat). Di dalamnya tercantum jadwal pelaksanaan perkawinan beserta sanksi/denda bila karena sesuatu dan lain hal perkawinan tersebut dibatalkan.

Bahan yang perlu dipersiapkan sebelum pelaksanaan pernikahan adat mata malam yaitu mempelai pria wajib membeli perangkat kecantikan dan peralatan mandi mempelai perempuan seperti; bedak, gincu, sabun mandi, parfum, handuk, sarung, sisir, sapu tangan, minyak rambut dan emas (cincin, kalung antinganting, maupun gelang) yang beratnya tidak kurang dari 2 gram. Khusus untuk bahan emas, bisa pilih salah satu, dari bagian di atas.Di samping bahan yang telah 
disebutkan di atas, ada pula bahan lainnya seperti babi yang beratnya tidak kurang dari $20 \mathrm{~kg}$, ayam kampung yang beratnya tidak kurang dari $10 \mathrm{~kg}$, tuak 1 tempayan berukuran sedang, mangkok kohang (mangkok berbahan keramik) sebanyak 20 singkap/buah, beras pulut putih kisaran $5 \mathrm{~kg}$ dan sejumlah uang (biasanya kisaran Rp 200.000). Bahan seperti mangkok kohang dan uang dibagi antar sesama pengurus kedua belah pihak. Sementara bahan-bahan lain dikonsumsi bersama semua warga yang hadir.

Setelah semua jenis bahan yang disebutkan di atas terkumpul, ketua adat menilai atau memeriksa, apakah bahan-bahan tersebut sudah sesuai dengan kriteria yang ditentukan atau belum. Jika ada diantara bahan tersebut yang belum tersedia, pernikahan tetap dilanjutkan, hanya saja mempelai pria kedepan (dalam waktu paling lama tiga hari) diwajibkan untuk memenuhi bahan adat tersebut. Bahan pernikahan yang masih kurang dan dipenuhi kemudian, harus disampaikan ataupun diketahui ketua adat. Sebelum bahan adat itu terpenuhi, kedua mempelai tidak diperkenankan tidur bersama dan tidak boleh melakukan hubungan badan, layaknya suami isteri. Apabila kedua mempelai tidur bersama dan telah melakukan hubungan suami-istriserta perempuan menjadi hamil, maka akan dituntut sanksi adat "Ngampang" (hamil di luar nikah), walaupun keduanya sudah menikah.

Tahap ketiga yaitu tahap pelaksanaan perkawinan adat berupa bahan adat. Setelah semua bahan terpenuhi maka ketua adat mengumumkan kepada warga bahwa kedua mempelai akan menikah dan apabila mempelai perempuan hamil sebelum mereka melangsungkan pesta pernikahan, keduanya tidak dikenakan sanksi adat Ngampang.Setelah acara inti selesai, mempelai bersama kedua orang tuanya masing-masing dikumpulkan oleh pengurus adat guna diberi wejangan atau nasihat tentang cara membangun rumah tangga yang baik, termasuk penentuan tempat tinggal kedua mempelai. Di samping itu, kedua mempelai diwajibkan untuk tidak menyebut nama mertua (kecuali dalam kondisi tertentu). Ini dimaksudkan supaya mereka menghargai orang tua khususnya keluarga terdekat dengan orang tua pasangannya. Tidak menyebut nama mertua karena mereka dianggap sebagai orang tua sendiri.

Adapun ritual atau upacara pernikahan adat mata malam sebagai berikut: a) ketua adat memeriksa semua alat kecantikan dan alat mandi yang disediakan oleh pihak laki-laki, b) disamping alat kecantikan dan mandi, terdapat pula mangkok keramik (kohang), tempayan dan piring keramik, c) setelah semua peralatan tersebut diperiksa ketua adat selanjutnya disengkelan dengan darah ayam dan babi, d) setelah disengkelan peralatan mandi dan kecantikan dikembalikan kepada kedua mempelai. Sementara, tempayan, mangkok dan piring dibagi oleh para pengurus adat antara kedua belah pihak, e) selanjutnya para pengurus adat dari kedua belah pihak minum tuak dari tempayan menggunakan bambu kecil (sumpit), f) pengurus adat dari kedua belah pihak memberikan nasihat bagaimana seharusnya hidup membangun rumah tangga yang baik.

Berdasarkan pengamatan dan hasil wawancara dengan tokoh adat berinisial AA menyatakan permasalahan yang muncul sehingga lunturnya pelaksanaan pernikahan adat mata malam subsuku Dayak Sawe adalahkurangnya keterlibatan anak usia muda dalam melaksanakan pernikahan adat mata malam. Kebiasaan zaman dulu bahwa anak muda dilarang untuk mengikuti pernikahan adat mata malam masih terasa mempengaruhi pola pikir tokoh adat zaman sekarang.Perkembangan teknologi komunikasi yang membawa nilai-nilai baru yang berbeda dengan adat mata malam,Masuknya budaya luar yang mempengaruhi pola pikir dan gaya hidup masyarakat Dayak Sawe yang sebelumnya memiliki ketaatan terhadap aturan budaya setempat namun lama kelamaan mulai ditinggalkan dan mengikuti budaya luar yang lebih modern. Permasalahan tersebut menjadi tantangan bagi tokoh adat sebagai penjaga tradisi dan pewaris tradisi.

Tokoh adat adalah seseorang yang memiliki jabatan adat dalam suatu tatanan masyarakat adat di suatu wilayah. Pengangkatan seorang tokoh adat biasanya berdasarkan turun temurun atau berdasarkan kesepakatan masyarakat adat karena memiliki kedudukan tertentu dalam masyarakat, orang-orang tua yang mampu mengetahui adat,mampu menjaga keberlangsungan adat dan dapat mewariskan adat[16].

Tokoh adat Dayak Sawe adalah orang-orang Dayak Sawe yang diangkat karena berdasarkan turun temurun atau berdasarkan kesepakatan masyarakat adat. Tokoh adat Dayak Sawe memiliki seorang ketua adat. MA sebagai tokoh adat Dayak Sawe mengatakan peran tokoh adat Dayak Sawe adalah mempersiapkan dan memimpin suatu upacara adat, mempertahankan cara hidup secara adat, menjelaskan makna dari suatu adat termasuk makna pernikahan adat mata malam, mewariskan cara hidup adat kepada generasi penerus melalui keterlibatan anak-anak muda dalam kegiatan adat. Tokoh adat berperan menjaga cara hidup secara adat dan mewariskan tradisi pada generasi muda. Peran tokoh adat Dayak Sawe dalam pernikahan adat mata malam adalah mempersiapkan upacara adat, menilai dan menentukan apakah bahan-bahan pernikahan sebagai pemenuhan adat mata malam sudah sesuai kriteria atau belum. Jika ketua adat menyatakan bahan tersebut belum sesuai, tentu harus dipenuhi dan disampaikan secara langsung kepada pengurus adat yang ada di wilayah setempat. Sebaliknya, jika ketua adat ataupun pengurus adat lainnya menyatakan bahwa bahan tersebut sudah sesuai, tentu pernikahan dilaksanakan dengan penuh khidmat. 


\section{B. METODE PENELITIAN}

Penelitian ini menggunakan pendekatan kualitatif deskriptif dengan jenis studi etnografi. Peneliti menggunakan pendekatan kualitatif karena hanya mendeskripsikan peran tokoh adat dalam melestarikan pernikahan adat mata malam subsuku Dayak Sawe. Peneliti menggunakan jenis studi etnografi karena berhubungan dengan budaya sutu etnik tertentu yaitu budaya Dayak Sawe. Studi etnografi adalah kajian tentang kehidupan dan kebudayaan suatu masyarakat atau etnik, misalnya tentang adat-istiadat, kebiasaan, hukum, seni, religi, bahasa dan lain sebagainya[18].

Tempat atau lokasi penelitian yaitu subsuku Dayak Sawe yang ada di Desa Nanga Biaban Kecamatan Sekadau Hulu Kabupaten Sekadau Kalimantan Barat. Subyek dalam penelitian adalah segala sesuatu yang berkaitan dengan peran tokoh adat dalam melestarikan pernikahan adat mata malam subsuku Dayak Sawe, yang dapat menunjang dalam memperoleh data. Subyek penelitian ditentukan dengan teknik purposive bersifat snowball sampling artinya peneliti menentukan sendiri sampel yang diambil karena pertimbangan tertentu yaitu berdasarkan tingkat pemahaman responden terhadap pernikahan adat Dayak Sawe. Adapun yang menjadi subyek dalam penelitian ini adalah tokoh adat Dayak Sawe, tokoh masyarakat dan tokoh agama.

Tahap pengumpulan data terdiri dari 3 tahap yakni tahap perencanaan, tahap pelaksanaan dan tahap analisis data. Tahap perencanaan dimulai dengan mengurus perijinan dan administrasi terkait dengan rencana pelaksanaan penelitian. Tahap pelaksanaan dimulai dengan menyusun instrumen penelitian berupa panduan observasi, panduan wawancara dan dokumentasi.Pada tahap pengumpulan data, peneliti terjun ke lapangan untuk melakukan observasi, wawancara dan dokumentasi kepada responden.

Pada tahap selanjutnya adalah tahap analisis data, setelah selesai proses pengumpulan data yang diperoleh sejumlah data kualitatif. Analisis data dan pengolahan data berpedoman pada data yang terkumpul dari hasil pengamatan dan wawancara. Data yang terkumpul dianalisis secara deskriptif. Pada tahap analisis data, penelitian kualitatif bersifat induktif bahwa semua kesimpulan dibentuk dari semua informan yang diperoleh dari lapangan. Teknik analisis data yang digunakan adalah teknik analisis data deskriptif kualitatif memanfaatkan persentase hanya merupakan langkah awal dari proses analisis data[19]. Selanjutnya analisis data kualitatif terdiri dari empat alur kegiatan yang terjadi secara bersamaan yaitu catatan lapangan, pengumpulan informasi, penyajian informasi dan penarikan kesimpulan[20].

\section{HASIL DAN PEMBAHASAN}

\section{Makna yang Terkandung dalam Pernikahan Adat Mata Malam}

Setiap kegiatan dipastikan ada makna yang tersirat di dalamnya. Makna yang terkandung dalam setiap kegiatan, tentu bergantung dari jenis maupun bentuk kegiatan tersebut. Dalam acara adat-istiadat, biasanya makna yang terkandung di dalamnya sering sarat dengan nilai religi. Nilai-nilai tersebut berupa kepercayaan terhadap Yang Maha Kuasa, nilai moral, nilai pergaulan hidup dengan sesama serta nilai hubungan manusia dengan alam.

Dalam pernikahan adat Dayak Sawe, terutama pada adat mata malam, menurut responden berinisial $\mathrm{AN}$, ada beberapa makna yang terkandung di dalamnya, antara lain: (1) kerukunan berupa pembinaan, nasihat hidup kedua mempelai supaya selalu hidup rukun dan damai di dalam rumah dan di masyarakat (2) ketaatan yaitu kedua mempelai taat kepada adat dan mempertahankan adat-istiadat; (3) pencegahan yaitumencegah kedua mempelai agar terhindar dari sanksi adat hamil di luar nikah; (4) Cinta akan Tuhan, alam dan sesama dengan menjaga keseimbanganhubungan manusia dengan Tuhan, alam dan sesama. Masyarakat Dayak Sawe cinta akan Tuhan dengan mengucapkan syukur kepada Tuhan atas rejeki kehidupan dan kesuksesan dalam bertani atau berladang melalui acara adat. Cinta akan sesama ditunjukkan dengan saling mengunjungi keluarga dan memperhatikan sesama dalam hal kekurangan. Cinta akan alam ditunjukkan dengan menjaga dan merawat alam agar tetap lestari. Namun tak bisa dipungkiri bahwa ada juga masyarakat yang merusak alam dengan menebang pohon dan menjual kepada pelaku bisnis.

Sementara itu, responden berinisial AM berpendapat bahwa makna yang terkandung dalam pernikahan adat mata malam adalah untuk menghindari pembicaraan warga lain yang bersifat negatif terhadap mempelai karena dengan adanya adat mata malam tersebut, secara adat kedua mempelai sudah sah sebagai suami istri, walaupun belum menikah secara gereja dan belum ada "buisnya" (pesta) pernikahan. Makna pernikahan adat mata malam tersebut lebih bersifat etis yaitu menjaga sopan santun, menjaga kedua mempelai dari praduga negatif yang dilihat dan dibicarakan masyarakat.

Responden berinisial MA berpendapat bahwa makna yang terkandung dalam pernikahan adat mata malam pada suku Dayak Sawe, antara lain: supaya kedua mempelai tidak merasa was-was ketika berjalan bersama, sebagai pertanda bahwa pasangan tersebut sudah menjadi suami istri. Artinya, menyebut pasangan bukan lagi sebagai "Pangan", melainkan sebagai Suami (laki) dan istri (bini).

Kesimpulannya bahwa pernikahan adat mata malam bermakna kerukunan, ketaatan, keseimbangan hubungan manusia denganTuhan, sesama, alam, 
menghindarkan kecurigaan orang lain terhadap kedua mempelai apabila sudah hidup bersama, menguatkan kedua mempelai supaya tidak takut untuk berjalan bersama di dalam masyarakat.

\section{Kendala yang dihadapi Tokoh Adat dalam Melestarikan Pernikahan Adat Mata Malam}

Temuan penelitian mengenai kendala yang dihadapi tokoh adat dalam melestarikan pernikahan adat mata malam, antara lain responden berinisial MS berpendapat bahwa dalam bidang adat, banyak sekali tantangan yang dihadapi, terutama oleh para generasi tua. Mereka khawatir jika adat yang diwariskan turun temurun dari para leluhur, tidak mampu lagi bertahan menghadapi tantangan zaman yang selalu berubah. Perkembangan teknologi komunikasi yang begitu cepat merupakan salah satu penyebab anak-anak muda zaman sekarang enggan belajar tentang adat. Generasi muda lebih tertarik pada dunia modern daripada adat. Mereka jauh lebih tertarik mengikuti perkembangan masa kini daripada mempertahankan apa yang sudah ada. Budaya luar yang membawa nilai-nilai baru dan mempengaruhi pola pikir dan gaya hidup masyarakat yang sebelumnya memiliki ketaatan terhadap aturan budaya setempat namun lama kelamaan mulai ditinggalkan dan mengikuti budaya luar yang lebih modern,

Sementara itu, responden berinisal PN menyatakan bahwa semakin hari tantangan hidup yang dihadapi semakin berat. Adat yang merupakan warisan nenek moyang kami, ruang geraknya semakin sempit dan ditinggalkan. Banyak anak-anak muda yang beranggapan adat tidak penting untuk dipertahankan, sehingga mereka lebih memilih mempelajari hal-hal di luar adat tersebut. Mereka yang ikut prosesi kegiatan adat seringkali tidak menyimak dengan baik apa yang disampaikan tokoh adat. Alhasil, mereka ketinggalan kesempatan penting dan pada akhirnya minim pengetahuan mengenai adat. Mereka lupa bahwa selama ini mereka hidup dalam pengaturan adat istiadat yang masih berusaha dipertahankan generasi tua.

Disamping itu, kendala yang dihadapi para tokoh adat dalam mewariskan adat mata malam, menurut SS antara lain; (1) mayoritas anak-anak jaman sekarang tidak menetap di kampung, mereka lebih banyak tinggal di kota maupun di daerah lain. Ini disebabkan pekerjaan, pernikahan maupun menempuh pendidikan. Ketika pulang ke kampung, mereka justru lebih banyak memahami budaya dari luar. Contohnya, setelah memasuki acara bebas dalam sebuah kegiatan adat, anak-anak muda mayoritas memilih berjoget dengan lagu-lagu daerah maupun dangdut daripada mendengarkan para tokoh adat bercengkrama tentang adat; (2) pengaruh teknologi mempunyai andil yang cukup besar sebagai penggeser kebudayaan; (3) anakanak muda lebih tertarik mempelajari segala sesuatu yang bersifat baru.

Sebenarnya tidak salah mempelajari sesuatu yang baru, namun akan menjadi permasalahan apabila kita terlena dengan sesuatu yang baru kemudian meninggalkan yang lama. Hidup manusia dalam mempertahankan adat tidak ubahnya seperti membeli motor. Kita memahami bahwa setiap tahun bahkan hampir setiap bulan keluar motor dengan gaya baru. Melihat sesuatu yang baru, timbul keinginan untuk memilikinya dan menjual yang lama. Padahal, yang baru, hanya dipoles sedikit supaya menarik minat konsumen. Inilah sifat dasar manusia yang cenderung mudah mencari sesuatu yang baru daripada mempertahankan ataupun memelihara yang lama.

Menurut responden berinisial AM, kendala yang mempengaruhi pelestarian pernikahan adat mata malam adalah agama. Dalam hal ini, masuknya agama dengan ajaran tentang keselamatan manusia bukan dari adat tetapi iman kepada Tuhan. Iman dan perbuatan baik adalah kunci keselamatan manusia itu sendiri, bukan melaksanakan adat yang kadang memberatkan masyarakat. Hal tersebut diperkuat dengan aturan negara yang mewajibkan bahwa setiap warga negara harus memiliki agama tertentu yang diakui oleh negara dan pemeluknya wajib menjalankan ajaran agama dalam kehidupan sehari-hari di masyarakat dengan baik. Mayoritas masyarakat lebih memahami tentang agama daripada ajaran budaya setempat. Hal tersebut dikarenakan ajaran agama sudah dibukukan dan dapat dibaca, sedangkan ajaran budaya masih bersifat lisan yang memerlukan daya ingat lumayan tinggi.

Pasangan yang menikah setelah masuknya agama, lebih memilih menikah menurut ajaran agama karena menurut mereka lebih mudah dan juga diakui atau disahkan oleh negara. Melalui surat yang dikeluarkan pengurus agama, pasangan yang sudah menikah dapat memperoleh surat nikah resmi dari Catatan Sipil yang dikeluarkan negara. Bahkan, pasangan yang menikah sebelum masuknya agama diwajibkan untuk menikah secara agama apabila mereka masih mempunyai anak yang sedang atau bahkan belum sekolah. Ini dimaksudkan sebagai syarat untuk mengurus surat pernikahan yang dikeluarkan negara dan selanjutnya surat tersebut dipergunakan sebagai syarat membuat akta kelahiran.

Menurut SS, kendala dalam melestarikan pernikahan adat mata malam adalah pergeseran kebudyaan yang dialami oleh masyarakat Dayak Sawe pada kenyataannya telah menyeret mereka pada kompleksitas fenomena global. Contoh fenomena global yang berkembang di dalam masyarakat Dayak Sawe adalah budaya konsumtif, artinya suatu perilaku membeli dan menggunakan barang yang tidak didasarkan pada pertimbangan rasional dan memiliki kecenderungan untuk mengkonsumsi sesuatu tanpa batas dimana individu lebih mementingkan keinginan daripada kebutuhan. Budaya konsumtif ini berimbas pada perilaku tidak peduli apabila berhubungan dengan persiapan bahan dalam pernikahan adat mata malam. Masyarakat Dayak Sawe khususnya generasi muda 
merasa sulit menyiapkan bahan yang dipergunakan sebagai syarat dalam pernikahan adat.

Menurut AM, kendala dalam melestarikan pernikahan adat mata malam adalah aturan pernikahan yang sangat ketat seperti harus ada emas, tidak boleh jalan bersama kalau belum nikah adat, tidak boleh perempuan hamil sebelum nikah adat. Pernikahan adat bisa dibatalkan jika salah satu syarat tidak terpenuhi. Aturan pernikahan adat mata malam yang sangat ketat tersebut memiliki sisi positif seperti menjaga keutuhan adat itu sendiri, menjaga martabat kesucian yaitu tidak boleh kedua mempelai berhubungan badan sebelum menikah bahkan tidak boleh jalan bersama. Sisi negatifnya adalah kedua mempelai tidak peduli dengan aturan adat dan tidak peduli dengan martabat kesucian tersebut karena kebanyakan anak muda yang sudah berpasangan melakukan hubungan badan sebelum menikah bahkan sampai hamil.

Kesimpulannya bahwa kendala yang dihadapi tokoh adat dalam melestarikan pernikahan adat mata malam adalah teknologi komunikasi danbudaya luar yang membawa nilai-nilai baru dan mempengaruhi pola pikir dan gaya hidup masyarakat yang sebelumnya memiliki ketaatan terhadap aturan budaya setempat namun lama kelamaan mulai ditinggalkan dan mengikuti budaya luar yang lebih modern, ruang geraknya adat semakin sempit dan ditinggalkan generasi muda sebagai penerus tradisi, banyak anak-anak muda mulai keluar atau meninggalkan kampung karena pekerjaan, perkawinan dan pendidikan, juga kendala karena masuknya agama dengan ajaran keselamatan karena iman kepada Tuhan bukan karena melaksanakan adat dan aturan negara yang lebih mesahkan pernikahan secara agama.

\section{Upaya yang dilakukan dalam Mengatasi Kendala Pelestarian Pernikahan Adat Mata Malam}

Temuan penelitian menunjukan bahwa upaya yang dilakukan dalam mengatasi kendala pelestarian pernikahan adat mata malam, sesuai dengan hasil wawancara dengan responden berinisial MT, antara lain: tokoh adat melibatkan anak usia muda dalam setiap kegiatan adat, memberikan pemahaman kepada masyarakat bahwa menikah secara adat sangat penting sebagai upaya menjaga kelestarian adat dan cinta akan adat, memberikan peluang kepada generasi muda untuk belajar mengenai adat. Generasi penerus tradisi tetap diberi pemahaman akan pentingnya menjaga tradisi sebagai tanda penghormatan kepada nenek moyang pencetus tradisi tersebut, hanya disesuaikan dengan keadaan zaman. Misalkan pernikahan adat mata malam tetap dijalankan dengan baik hanya bahan persiapan pernikahan tidak boleh menuntut wajib dan harus dipenuhi.

Responden berinisial AN, berpendapat bahwa para tokoh adat melakukan pembinaan terhadap kaum muda-mudi, yakni dengan mengagendakan secara rutin kunjungan ke setiap perkampungan Dayak Sawe yang letaknya tidak berjauhan. Dalam kunjungan tersebut para muda-mudi selalu dilibatkan dalam proses adat, baik pernikahan maupun acara adat yang lainnya. Kunjungan tersebut, biasanya dilaksanakan setahun sekali, yakni berkisar antara bulan Mei sampai Juli, dimana pada bulan-bulan tersebut bertepatan dengan hari gawai dayak.

Selain melakukan kunjungan terhadap perkampungan sesama Dayak Sawe, para muda-mudi juga sering bertamu ke daerah lain yang berbeda sub sukunya, seperti Dayak Taman, Dayak Ketungau Sesai'k, Dayak Kerabat dan Dayak Jawan. Dalam kunjungan tersebut, mereka melakukan studi banding soal budaya. Mereka juga berkesempatan menyampaikan adatistiadat yang berlaku di daerahnya masing-masing.

Responden berinisial PN menyatakan bahwa upaya yang dilakukan guna melestarikan pernikahan adat mata malam, antara lain: memberikan pemahaman kepada masyarakat bahwa menikah secara adat sangat penting sebagai upaya menjaga kelestarian adat tersebut. Namun, menikah menurut ajaran agama juga penting sebagai persyaratan berurusan dengan negara, karena menikah secara adat sejauh ini tidak ada surat yang dikeluarkan yang sekiranya surat tersebut dapat dipergunakan untuk berurusan dengan negara. Dalam hal ini, masyarakat selalu disarankan untuk menikah menurut adat setempat dan juga ajaran agama. Ini berarti keduanya sama-sama dilaksanakan, karena mengingat adat maupun agama memegang peranan penting dalam kehidupan manusia.

Menurut responden berinisial SS mengatakan tokoh adat seharusnya juga mulai terbuka dengan perkembangan arus modernisasi yang tidak bisa dihindari masyarakat dimanapun. Keterbukaan tokoh adat ditunjukkan dengan perubahan paradigma atau pola pikir, pola sikap terhadap hadirnya budaya baru, nilai-nilai baru. Perubahan pola pikir dalam hal pernikahan adat mata malam yaitu pernikahan adat tidak boleh dipaksakan atau diharuskan menyiapkan bahan pernikahan secara lengkap seperti zaman dulu, yang penting kedua mempelai mau menikah secara adat itu sudah sesuatu yang bagus. Pola sikap terhadap pernikahan adat mata malam seperti peduli dengan pasangan yang mau menikah secara adat dan peduli juga dengan pasangan yang tidak mau menikah secara adat tetapi menikah secara agama. Diutamakan adalah kebahagiaan yang dirasakan dan dialami kedua mempelai dalam menjalani kehidupan rumah tangga.

Responden AA memperkuat pernyataan pendapat tokoh adat SS bahwa upaya yang dilakukan adalah adaptasi masyarakat adat dengan budaya baru yaitu menyesuaikan diri dengan datangnya budaya baru yang tidak bisa dihindari, sehingga terjadi akulturasi budaya. Generasi muda menerima budaya baru sebagai bentuk 
penyesuaian diri dengan lingkungan dan menyesuaikan diri untuk kebutuhannya. Adanya keterbukaan terhadap ajaran agama Kristen yang mengutamakan iman dan perbuatan baik, namun tidak boleh menghilangkan substansi dari pelaksanaan pernikahan adat Mata Malam karena ada nilai yang diambil dari pernikahan adat tersebut seperti menjaga kesucian pernikahan, mengatur kereligiusan proses pernikahan dan menjaga etika dan moral pernikahan adat mata malam seperti calon mempelai tidak boleh berjalan bersama dan berhubungan suami istri sebelum menikah secara adat,

\section{SIMPULAN DAN SARAN}

Pernikahan adat mata malam memiliki tiga tahap yaitu tahap pertama sebagai pendekatan awal dimana pihak laki-laki mendatangi pihak perempuan mengutarakan maksud mengadakan ikatan antara anak pihak laki-laki dengan anak pihak perempuan. Tahap kedua yaitu pertunangan, dimana pihak laki-laki menyerahkan sejumlah barang kepada pihak perempuan Tahap ketiga yaitu tahap pelaksanaan perkawinan adat berupa pemenuhan hukum adat. Pernikahan adat mata malam ini mengandung makna kerukunan, ketaatan, keseimbangan hubungan manusia dengan Tuhan,alam dan sesama. Dalam perkembangan pernikahan adat mata malam ini, tokoh adat mengalami kendala dalam pelestariannya karena perkembangan teknologi komunikasi, masuknya budaya luar, generasi muda lebih tertarik pada dunia modern daripada adat, kendala masuknya agama yang mengajarkan tentang pentingnya iman kepada Tuhan daripada tradisi.

Upaya yang dilakukan para tokoh adat dalam melestarikan pernikahan adat mata malam tersebut yaitu melibatkan secara langsung anak-anak muda untuk mengikuti berbagai kegiatan yang berkaitan dengan adat; memberikan pemahaman kepada masyarakat bahwa menikah secara adat sangat penting sebagai upaya menjaga kelestarian adat dan cinta akan adat. Upaya lainnya yaitu mengurangi bahan persiapan pernikahan dengan memperhatikan tingkat ekonomi masyarakat yang kadang kurang pendapatannya, adanya keterbukaan terhadap perkembangan arus modernisasi dan adaptasi terhadap masuknya budaya baru.

\section{UCAPAN TERIMA KASIH}

Peneliti mengucapkan terima kasih kepada berbagai pihak yang telah membantu proses penelitian ini. antara lain: (1) LPPM STKIP Persada Khatulistiwa Sintang yang telah memberikan informasi terkait hibah penelitian tahun 2019, (2) Kemenristekdikti yang telah memberikan bantuan berupa dana hibah penelitian, (3) Tokoh adat, tokoh agama dan masyarakat Desa Nanga Biaban yang telah bersedia memberikan informasi terkait data penelitian,(4) Pengelolah Civicus Universitas Muhammadiyah Mataram yang bersedia mempublish artikel ini. Semoga hasil penelitian ini bermanfaat bagi masyarakat Indonesia, khususnya masyarakat adat sub suku Dayak Sawe Kabupaten Sekadau Kalimantan Barat.

\section{DAFTAR RUJUKAN}

[1] Soekanto., Sosiologi Suatu Pengantar. Jakarta : Grafisi Press.2012.

[2] Kistanto,. "Sistem Sosial-Budaya di Indonesia", Sabda

Jurnal Kajian Kebudayaan. Vol. 3, No.1, h. 99-105.2008.

[3] Koentjaraninggrat. Pengantar Ilmu Antropologi. Jakarta: PT.Rineka Cipta.2009.

[4] Ranjabar. Sistem Sosial Budaya Indonesia. Bogor: GhaliaIndonesia.2006.

[6] Garna. Budaya Sunda: Melintasi Waktu Menantang Masa Depan. Bandung: Lemlit Unpad.2008.

[7] Prasetiyo. "Pelaksanaan Perkawinan dan Pewarisan Masyarakat Adat Sedulur Sikep Desa Baturejo, Kecamatan Sukolilo, Kabupaten Pati”. Sos Bud. Vol 7, No. 1, h. 21-30.2014.

[8] Mariane. Kearifan Lokal Pengelolaan Hutan Adat. Jakarta: PT. Raja Grafindo Persada.2014.

[9] Kuntowijoyo. Budaya dan Masyarakat. Yogyakarta: Tiara Wacana.2006.

[10] Babul. "Pergeseran Budaya Lokal Remaja Suku Tengger di Desa Argosari Kecamatan Senduro Kabupaten Lumajang”. JESS Vol.No.1, h. 20-28. 2017.

[11] Narwoko. Sosiologi:Teks Pengantar dan Terapan. Jakarta: Prenada Media Group.2006.

[12] Hilmi. Nilai-nilai Kearifan Lokal dalam Perilaku Sosial Anak-Anak Remaja di Desa Sepit Kecamatan Keruak Lombok Timur. Tesis. Semarang: Progam Pascasarjana Unnes.2015.

[13] Hanan, Himasari. "Modernization and Cultural Transformation: The Expansion of Traditional Batak Toba House in Huta Siallagan”. Social and Behavioral Sciences. Vol 50, h. 80o-811.2012.

[14] Undang-Undang Tentang Perkawinan Nomor 1 Tahun 1974.

[15] Hilman, Hadikusuma. Hukum Perkawinan menurut perundangan hukum adat, hukum agama : Bandung : Mandar Maju. 2003.

[16] Depdiknas. Kamus Besar Bahasa Indonesia. Edisi Ketiga. Jakarta: Balai Pustaka.2005.

[17] Berry. Pokok-Pokok Pikiran dalam Sosiologi. Jakarta: PT. Raja Grafindo Persada. 2003.

[18] Kuswarno, E. Metode Penelitian Komunikasi: Etnografi Komunikasi.Bandung: Alfa Beta.2008.

[19] Arikunto, Suharsimi. Prosedur Penelitian Suatu Pendekatan Praktik. Jakarta: Rineka Cipta.2009.

[20] Sugiyono. Metode Penelitian Pendidikan, Pendekatan Kuantitatif, Kualitatif \& R\&D.Bandung: PT. Alfabeta. 